\title{
UNIVERSIDADE MEDIEVAL NO SÉCULO XIII: UM ESTUDO DE SUAS ORIGENS SOB 0 OLHAR DA HISTORIOGRAFIA FRANCESA
}

\author{
UNIVERSITY IN MEDIEVAL XIII CENTURY: A STUDY OF ITS ORIGINS \\ ACCORDING TO FRENCH HISTORIOGRAPHY
}

\section{UNIVERSIDAD MEDIEVAL EN EL SIGLO XIII: UN ESTUDIO DE SUS ORÍGENES DESDE LA MIRADA DE LA HISTORIOGRAFÍA FRANCESA}

Ana Paula dos Santos Viana* Terezinha Oliveira**

\begin{abstract}
Resumo: Neste texto apresentamos um estudo a respeito da universidade medieval presente na História da Educação. Nosso propósito é analisar suas origens no século XIII, por meio do estudo das interpretações historiográficas francesas produzidas no século XX, com ênfase nos medievalistas franceses Jacques Le Goff e Jacques Verger. Além das obras desses autores, utilizamos outras obras de autores contemporâneos que se dedicaram ao estudo dessa instituição e período. Preocupados com o sentido de formação docente, estudaremos as origens das universidades, onde essa formação se inicia. Acreditamos que as formulações historiográficas mostram a importância das universidades como instituições que primam pela preservação e pela estruturação do saber, sendo que tal instituição permanece sendo o espaço da formação docente. Desse modo, é necessário entender as reflexões dos autores em análise em consonância com as questões históricas. A metodologia escolhida foi a História Social, sob a qual tentamos observar o objeto considerando-o como parte constituinte da totalidade histórica.
\end{abstract}

Palavras-chave: História da educação medieval. Universidade medieval. Escolástica.

\begin{abstract}
This paper is a study about the medieval university in the History of Education. Our purpose is to analyze its origins in the third century through the study of French historiographical interpretations produced in the twentieth century, with emphasis on the French medievalists Jacques Le Goff and Jacques Verger. Besides the works of these authors, we used other contemporary authors who have studied these institutions and period. Concerned with the direction of teacher training, we will study its origins - at the Universities. We believe that historiographical formulations show the importance of universities as institutions which prioritize to preserve and structure the knowledge - and this institution still is the space for teacher training. Therefore, it is necessary to understand the reflections of the authors under review in line with historical issues. The methodology chosen was Social History, under which we try to observe the object considering it as a constituent of the historical totality.
\end{abstract}

Keywords: History of medieval education. Medieval university. Scholastic.

\footnotetext{
* Mestranda em Educação pela Universidade Estadual de Maringá. Correio eletrônico: ana_psviana@hotmail.com.

** Doutora em História pela Universidade Estadual Paulista Júlio de Mesquita Filho. Professora Associada do Programa de Pós-Graduação em Educação da Universidade Estadual de Maringá. Correio eletrônico: teleoliv@gmail.com.
} 
Resumen: En este texto presentamos un estudio a respeto de la universidad medieval presente en la Historia de la Educación. Nuestro propósito es analizar sus orígenes en el siglo XIII, por medio del estudio de las interpretaciones historiográficas francesas producidas en el siglo XX, con énfasis en los medievalistas franceses Jacques Le Goff y Jacques Verger. Además de las obras de estos autores, utilizamos otras obras de autores contemporáneos que se dedicaron al estudio de esta institución y periodo. Preocupados con el sentido de formación docente, estudiaremos los orígenes de las universidades, donde se inicia esta formación. Creemos que las formulaciones historiográficas muestran la importancia de las universidades como instituciones que priman por la preservación y la estructuración del saber, y tal institución permanece siendo el espacio de la formación docente. De este modo, hay que entender las reflexiones de los autores en análisis en consonancia con las cuestiones históricas. La metodología elegida ha sido la Historia Social, bajo la cual tentamos observar el objeto considerándolo como parte constituyente de la totalidad histórica.

Palabras clave: Historia de la educación medieval. Universidad medieval. Escolástica.

\section{Introdução}

Ao iniciar-se uma carreira acadêmica, ou ao ingressar-se na profissão docente, independentemente do nível de ensino, por vezes é esquecido o modo como se consolidou esse espaço de formação - a Universidade. Observamos as crescentes críticas que a educação brasileira ${ }^{1}$ recebe, bem como as implicações intimamente ligadas a esta, porém dificilmente conseguimos entendê-las e, assim, melhorá-las. Dentro dessa perspectiva, como educadoras que presenciam os debates que permeiam a educação no Brasil, começamos a nos indagar: será que nos inquietamos em saber como as universidades se constituíram? Como vemos nossa formação docente, humana e intelectual? Será que essas formações estão interligadas?

1. Dentre as notícias e estatísticas frequentemente divulgadas, destacamos duas: a falta de leitura expressa pelos dados estatísticos de analfabetismo no Brasil: 10 a 14 anos (3,9\%); 15 ou mais (9,6\%). Fonte: PNAD/ IBGE - 2010. Outra notícia preocupante refere-se à nota divulgada pelo jornal O Estado de S. Paulo (do dia 26 de agosto de 2011): a avaliação (Prova ABC) feita por 6 mil estudantes das redes pública e privada das capitais revela que $44 \%$ leem mal, $46 \%$ escrevem errado e 57\% têm sérias dificuldades em Matemática. Fonte: Texto de Mandelli (2011) divulgada em < www. estadao.com.br>.
A inquietação causada por essa problemática, que vem do início de nossa vida acadêmica, nos levou a estudar o tema e tentar nos aproximar do cerne dessa questão. Observamos que seria oportuno recuperar as origens do local onde se inicia nossa formação, o espaço do saber representado pela universidade.

Ao longo da graduação, observamos que tempos da história anteriores ao nosso são fundamentais para alimentar a reflexão e também para que entendamos algumas questões cotidianas - não porque determinado tempo proporciona respostas, mas porque nos permite refletir e perceber o quanto de resquícios o tempo presente resguarda do passado. Desse modo, apresentaremos um estudo procurando evidenciar as origens da universidade amparada na História da Educação.

Realizar um estudo recuperando a Idade Média no campo da História da Educação é um desafio, pois nos permite encontrar muitas fontes de pesquisa nessa área do saber. Isto porque se trata de um período longo da história. Desse modo, há ainda muito que compreender. Em nosso estudo, realizamos um recorte da História da Educação Medieval, a fim de focalizar o processo histórico do século XIII que contribuiu para o nascimento e o desenvolvimento das 
universidades medievais - e, por conseguinte, entender a contribuição do método escolástico no desenvolvimento da educação e do ensino nas cidades medievais dessa época.

Para tanto, estudamos as obras de autores que se dedicaram a esse período, como Jacques Le Goff, Jacques Verger, Marc Bloch, Henri Pirenne, Oliveira, dentre outros. Elegemos os autores contemporâneos, especialmente Le Goff (2007) e Verger (2001), por serem reconhecidos como autoridades nessa temática.

Assim, nossos objetivos incidiram em recuperar, nas obras analisadas, as origens da universidade medieval, considerando-a como novo local de estruturação e preservação do saber, interligada com os interesses da comunidade e os poderes laicos e eclesiásticos (as formulações historiográficas mostram a importância das universidades como instituições que primam pelo conhecimento).

Ao contemplarmos as origens da universidade medieval, estamos considerando as formulações dos autores mencionados, pois existe um grande debate acerca das origens da universidade na História, na história da Filosofia e na história da Educação. Algumas interpretações buscam as origens da universidade medieval nas escolas romanas; outras, a partir das escolas palatinas, e outras ainda afirmam que elas principiaram na antiga tradição das escolas do Oriente. Todavia, em virtude das abordagens realizadas pelos autores selecionados para estudo, ou seja, de acordo com a historiografia francesa referente às universidades no medievo, consideramos o seu surgimento entre o final do século XII e o início do século XIII, à medida que a entendemos como corporação, o que se caracteriza como um fenômeno próprio daquele período.

Essa abordagem do objeto, tal como a parte da totalidade expressa pela sociedade do período estudado, remonta ao método da História Social - que, de acordo com a historiografia, surgiu da revista dos Annales, fundada por Marc Bloch e Lucien Febvre em 1929, na França. Esses autores propunham a noção de História como problema e defenderam a ideia de que a História deve contemplar diferentes campos do conhecimento, como a Sociologia, a Antropologia, a Literatura e outros. Segundo eles, esses conhecimentos, aliados aos saberes produzido na sociedade, possibilitariam a compreensão das situações do presente.

Observar e estudar o passado expressa outro desafio, o de compreendê-lo sem a finalidade de estabelecer julgamentos, visto que cada época expressa maneiras de pensar e agir, pois os homens respondem a questões e demandas de um determinado tempo histórico. Ao fazermos isso, compreendemos e nos aproximamos de forma mais efetiva do contexto de cada existência humana, como afirma Bloch (2001, p.126):

[...] se o julgamento apenas acompanhava a explicação, o leitor estará livre para pular a página. Por infelicidade, à força de julgar, acaba-se, quase fatalmente, por perder até o gosto de explicar. Com as paixões do passado misturando seus reflexos aos partis pris do presente, o olhar se turva sem remédio e, assim como o mundo dos maniqueus, a humana realidade vira apenas um quadro em preto e branco. Montaigne já nos chamara a atenção: "A partir do momento em que o julgamento pende para um lado, não se pode evitar contornar e distorcer a narração nesse viés.” Do mesmo modo, para penetrar uma consciência estranha separada de nós pelo intervalo das gerações, é preciso quase se despojar de seu próprio eu.

Nessa passagem, o autor indica que não nos cabe julgar, com a finalidade de apresentar o certo e o errado, especialmente

Olhar de professor, Ponta Grossa, 16(1): 215-232, 2013. Disponível em <http://www.uepg.br/olhardeprofessor> 
no que se refere ao campo da História. O que deve nortear nossos estudos é a compreensão dos acontecimentos históricos. Entendemos que, ao conduzir nosso estudo à História, em busca de compreender uma instituição, é necessário voltarmos a atenção para a própria instituição e o contexto em que esta foi gestada.

Outro fundamento que sustenta nosso trabalho é o fato de julgarmos importante a compreensão do processo educativo medieval para entender a sociedade medieva. De acordo com Oliveira (2005):

[...] a Escolástica não foi apenas um método ou aspecto intelectual isolado, que provém da criatividade de alguns teóricos medievais, mas sim a maneira como os homens medievais realizavam suas ações. Trata-se de uma nova forma de pensar da sociedade, desde o mais humilde até o soberano. Caracteriza-se por ser a forma de os medievais pensarem e responderem "às questões humanas de sua época” [...]

[...] Com efeito, em sua essência, a Escolástica busca explicar o homem em sua fé e em sua natureza humana. Por isso [...] antes de tudo, devemos considerá-la como uma forma de explicar a essência do ser humano e da natureza em uma dada época histórica (OLIVEIRA, 2005, p.10).

A autora justifica a importância da Escolástica para os homens medievais, pois ela constitui a essência do pensamento no qual se encontravam os saberes e os valores imprescindíveis à sua regulamentação/organização nas relações sociais, bem como as explicações teóricas para diversos aspectos naturais e sociais.

Ressaltamos que pensamos como os autores estudados, que o homem é um ser social, que sofre mudanças no tempo. Também observamos que, em virtude desse entendimento, o homem do medievo apresenta mudanças ao longo do processo histórico, e é justamente nessas mudanças que verificamos os elementos que interferiram e estimularam o nascimento das universidades.

Neste sentido, a análise de nosso objeto pelo viés da História Social constitui o caminho a que almejamos chegar, haja vista que o desenvolvimento da educação medieval, sobretudo o das universidades, faz parte de um processo que envolve não apenas a cultura, mas todas as esferas da ambiência citadina do século XIII.

\section{Século XIII: o contexto histórico e a corporação universitária}

Principiaremos nossa abordagem fazendo considerações sobre o contexto histórico em que a universidade foi gestada, observando que essa instituição e o método escolástico são oriundos das transformações sociais que vinham ocorrendo desde fins do século XII e início do século XIII. Esse período, segundo Le Goff (2005), foi marcado por transformações sociais, dentre as quais o renascimento comercial e urbano proveniente da consolidação do sistema feudal.

Com relação ao renascimento urbano, o movimento e o desenvolvimento das cidades medievais se devem a um conjunto complexo de estímulos e a diversos grupos. Dentre esses, estão os homens evadidos do campo, das famílias monásticas, os quais estavam prontos a negociar e obter ganhos. Outro grupo era composto por agentes senhoriais saídos da escravidão e da servidão, denominados ministeriales, que logo se elevaram às camadas superiores da hierarquia feudal (LE GOFF, 2005).

Outro fato relevante para a compreensão do nascimento das cidades e da universidade vincula-se ao desenvolvimento das atividades agrícolas. Le Goff (2005), em 
A civilização do Ocidente medieval, assinala que o desenvolvimento agrícola provavelmente nasceu das exigências dos senhores feudais sobre os camponeses, bem como do surgimento, a partir do século $X$, de novas técnicas agrícolas.

Le Goff (2005) propala que o crescimento populacional e o desenvolvimento feudal marcaram o início do crescimento da cristandade medieval após a Alta Idade Média. O comércio desempenhou papel capital na expansão da economia monetária. Como centros de consumo e de troca, as cidades passaram a fazer uso da moeda para regular suas transações. Ao introduzi-las nas áreas rurais, modificaram a renda feudal. Com isso, o progresso da economia monetária torna-se elemento crucial na transformação do Ocidente medieval.

A respeito dessa questão, observamos as palavras de Le Goff (2007, p.168):

[...] a evolução das técnicas comerciais e, em particular, o papel cada vez maior das "escrituras" no ofício dos mercadores banqueiros, fez desenvolver-se entre os mercadores o que se chamou de cultura intelectual do mercador. Essa demanda cultural dos comerciantes levou à criação de escolas secundárias urbanas, como se vê em Gand desde 1179. Ela levou ao desenvolvimento de uma laicização da cultura pela promoção e pela difusão da escrita, do cálculo, da geografia e das línguas vivas.

De acordo com o medievalista francês, diante de novas necessidades e demandas, os mercadores-banqueiros necessitaram de uma nova forma de saber, cuja iniciativa proporcionou um caráter revolucionário para a forma de ensino, pois, antes, o conhecimento estava restrito à Igreja e aos nobres, e, a partir do renascimento comercial e urbano, esse quadro de restrição muda, ainda que o poder religioso permaneça forte. $\mathrm{Na}$ figura do mercador, identificamos esse papel ou influência inicial na transformação do ensino.

Essas novas necessidades apontadas por Le Goff já haviam sido destacadas por Pirenne (1964), quando este analisou o renascimento comercial no Ocidente medievo. Pirenne (1964, p.180-1) assevera que “o ensino cessa de repartir exclusivamente os seus benefícios pelos noviços dos mosteiros e pelos futuros padres das paróquias. Sendo o conhecimento da leitura e da escrita indispensável à prática do comércio [...]”.

Assim, em consonância com o surgimento dos vários ofícios que visavam à produção de bens de consumo (o cultivo da terra, a produção dos artesãos), encontra-se a figura do professor ou intelectual. Segundo Le Goff (2007, p.174):

O mestre universitário acumulara, assim, um trabalho de reflexão e de escrita, que chamaríamos hoje de pesquisa, e um trabalho de ensino. Para muitos, a sua reputação, suas intervenções em debates sociais e políticos (por exemplo, a mendicância dos religiosos, os poderes reais, a fiscalidade pontifícia) acrescentavam a sua função um papel que, desde o século XIX, foi em geral reconhecido aos intelectuais. Este é o motivo por que chamei esses universitários de "os intelectuais da Idade Média”.

Notamos nessa assertiva que o autor, explicando o nascimento desse novo homem, incumbido de despertar nos alunos o desejo pelo saber e a reflexão sobre as inquietações e demandas de sua época, revela que esse papel social dos intelectuais incide no que hoje chamamos de pesquisa, e que eles tinham a função de conduzir seus alunos à leitura e à escrita. Esse era o trabalho de ensino; esse era seu ofício. 
Podemos contextualizar o ofício de professor com auxílio do historiador Jacques Verger, que afirma, em sua obra Cultura ensino e sociedade no Ocidente nos séculos XII e XIII, que Pedro Abelardo (1079-1142) foi um dos maiores expoentes desse novo ofício, dessa nova realidade social, como profissional do saber. Verger (2001, p.44) identifica em Abelardo a renovação na dialética, a fundamentação da teoria escolástica, e postula que ele teria sido o primeiro moralista moderno ${ }^{2}$.

Nessa perspectiva, as formulações de Le Goff, a nosso ver, podem ser associadas às de Verger. Le Goff (1995), em Os intelectuais da Idade Média, discorre sobre o caminho percorrido por Abelardo. O historiador afirma que Pedro Abelardo foi o primeiro professor, especialista em lógica, que contribuiu na retomada da discussão entre fé e razão (escolástica), além de fundamentar os debates que colaboraram com o desenvolvimento do método dialético para o saber.

\begin{abstract}
Abelardo foi primeiro um especialista em lógica e, como todos os grandes filósofos, estabeleceu antes de tudo um método. Foi um grande defensor da dialética. Com seu Manual de Lógica para Iniciantes (Logica Ingredientibus), e sobretudo com seu Sic et Non de 1122, deu ao pensamento ocidental seu primeiro Discurso sobre o
\end{abstract}

2. Le Goff (1995, p.47) afirma que Pedro Abelardo (1079-1142), além de especialista em lógica, também foi especialista em moral. Para tanto, cita sua obra intitulada Ética ou Conhece-te a ti mesmo (Ethica seu Scito te Ipsum), na qual, como cristão nutrido na filosofia antiga, Abelardo atribui à introspecção um sentido amplo, em que o cristão é, antes de tudo, uma meditação sobre a importância do homem pecador. O conhecimento de si aparece na Ética como análise do livre-arbítrio, pelo qual cabe ao homem aceitar ou recusar o desprezo de Deus, que constituiu o pecado. Desse modo, Abelardo debate e mostra que o pecado não é uma substância, pois ele consiste mais em uma ausência do que em uma presença. E reclama para o homem o poder de consentir, isto é, o consentimento ou a recusa de dados à equidade, que é centro da vida moral.
Método. Neste livro ele prova, com uma extraordinária simplicidade, a necessidade de se recorrer ao raciocínio, pois não estão, em questão alguma, de acordo com os padres; onde um diz branco, outro diz negro: Sic et Non (LE GOFF, 1995, p.46).

Observa-se que Pedro Abelardo foi um dos expoentes dessa nova realidade de ensino, revelando, em sua obra História das minhas calamidades - Historia Calamitatum o quanto a antiga forma de ensino não estava mais adequada às questões/demandas dessa nova realidade social - e que, portanto, não possuía mais função. Desse modo, retomamos esse filósofo do século XII para retratar que, com o renascimento nas cidades e, por conseguinte, com os ofícios nela expressos, o intelectual precisa vincular o conhecimento com a prática. Ao traçarmos esse paralelo, podemos vincular o surgimento desse intelectual ao nascimento do mercador, como esclarece Le Goff (2007):

[...] O surgimento do mestre universitário, na Europa do século XIII, é paralelo ao surgimento do mercador. O mercador, acusado primeiro de vender o tempo que não pertencia senão a Deus (o benefício do lucro chega a [sic] comerciante mesmo dormindo), justificado depois, no século XIII, por seu trabalho e por sua utilidade, forma uma espécie de par como o mestre universitário, ele também acusado, no século XIII, de vender um bem que só pertence a Deus, a ciência, e que também foi justificado pelo trabalho que realizava ao ensinar estudantes que podiam assim lhe pagar pelas lições. Uma Europa do trabalho intelectual nascia ao lado da Europa do trabalho comercial (p.173-174).

Portanto, as características destacadas em Abelardo são aquelas dos professores que formariam as corporações universitárias posteriormente, ou seja, sendo este um homem de ofício, é preciso que soubesse 
estabelecer relações entre ciência e ensino, ter clareza de que o conhecimento precisa ser proferido na e para a sociedade, e com isso, nela cumprir seu ofício.

Esses personagens passaram a desempenhar funções sociais e políticas no seio da comunidade, ora a serviço do papa, ora a serviço do príncipe, ora a serviço de ambos. Nessa perspectiva, Oliveira (2007, p.123) afirma que:

A proximidade com o poder propiciava aos intelectuais uma inserção política e cultural significativa na sociedade, pois, em geral, legislavam a favor ou contra as autoridades, questionavam ou assimilavam os antigos conhecimentos sagrados ou filosóficos. Tudo isso dava certa autonomia às universidades com relação à comunidade local, permitindo-lhes uma liberdade de atuação cultural, científica e política que foi fundamental para o desenvolvimento do pensamento.

A questão analisada por Oliveira em relação à atuação política dos profissionais do saber foi anteriormente considerada por Verger (2001), quando este salienta que tais poderes - laicos e eclesiásticos - tiveram suma importância para a constituição das universidades, uma vez que:

Sem a ação dos príncipes e dos Papas, a passagem das escolas do século XII às universidades que vão ocupar a dianteira da cena no século XIII teria provavelmente sido impossível. Este elemento de contexto permite também compreender que esta mutação tenha sido feita, ao menos num primeiro momento, somente em um número limitado de locais, proporcionais ao número e às necessidades ainda relativamente limitadas destes novos poderes soberanos. [...] Os Papas e os príncipes do fim do século XII e do início do século XIII também tinham a sensação, provavelmente exagerada mas muito viva, de dever enfrentar sem cessar perigos cada vez maiores, que exigiam o uso de armas intelectuais até então inéditas (VERGER, 2001, p.184-185).

O autor destaca o papel social que os mestres universitários desempenhavam no seio da comunidade por expressarem com seus saberes, verdadeira “armas". Os papas e os príncipes observavam os mestres como pontos de apoio, pois o conhecimento destes era importante para exercerem e/ou efetivarem seus poderes. Cumpre observar que tais papéis e a instituição (universidade) são possíveis por se processarem na ambiência das cidades. É justamente lutando ou buscando apoio contra os poderes, ora eclesiásticos ora laicos, que essa instituição adquire sua autonomia. Essa questão também é encontrada em Oliveira (2007, p.120):

No início do século XIII, o papa e os príncipes encaravam essas instituições como importantes pontos de apoio político e cultural. Em função disso, editaram leis e bulas com o objetivo de instituí-las, protegê-las e nelas intervir, tanto no ensino como nas relações entre estudantes e mestres e entre estes e a comunidade.

A autora elucida o motivo pelo qual esses poderes disputavam entre si para ter a universidade como aliada, porque os poderes civis e eclesiásticos viam vantagens com a presença universitária, como enuncia Verger (2001, p.185): “O papado precisa dos magistri para pregar a Cruzada, reforçar a doutrina e formar os clérigos para a ação pastoral e sacramental".

Desse modo, vários foram os acontecimentos $^{3} \mathrm{e}$ as transformações que interferiram

3. Como já mencionamos: o renascimento das cidades, o florescimento do comércio, do mercador e o desenvolvimento das corporações de ofício (sendo uma destas, a universidade). 
no nascimento das universidades e o estimularam. Contudo, é necessário ressaltar que consideramos essa instituição como patrimônio histórico, ou seja, como instituição cuja preservação e cuja recordação são necessárias, uma vez que a universidade se tornou historicamente um local onde proliferaram, difundiram-se e ainda são difundidas as experiências humanas profícuas e essenciais no que tange à busca do conhecimento.

Essa consideração não pretende tecer comparações entre a universidade medieval e a atual, muito menos implica dizer que fora desta instituição não se produzem e se difundem muitos saberes. Ao contrário, compreendemos que a apropriação do conhecimento pode ser encontrada em outras formas ${ }^{4}$ e não apenas institucionalmente.

Além disso, decorridos séculos da criação da universidade, a história nos mostrou qual o caminho e a tendência que prevaleceram. Ela nos mostrou também que o debate que emergiu direcionou a um novo conhecimento, não mais pautado somente pela fé. Paulatinamente, a razão foi adquirindo força nas ciências, que possibilitaram novas teorias sobre poder, ciência, entre outros.

Contudo, o propósito deste estudo é chamar a atenção para o sentido do seja universidade no medievo. Encontramos nas palavras de Pieper o significado de universitas, uma vez que a noção de totalidade permeia metodologicamente o estudo e a exposição, com as quais possibilita a compreensão dessa instituição em sua essência, a da universalidade.

De fato, por mais que em sua realidade concreta nossas universidades se difiram das escolas superiores da cristandade medieval (e nem podia esperar outra coisa),

4. Afinal isso implica humanizar o homem em suas ações, comportamento, hábitos, em processos e tanto outros aspectos apontados por Libâneo (1998). mesmo assim elas realizam a mesma concepção fundamental que se exprime sob o nome de universitas: uma instituição que, de modo específico e singular, está relacionada com a totalidade do real, com o mundo como um todo. (PIEPER, 1989, p.23).

Um homem formado, afirma o referido autor, é aquele que sabe se relacionar como o mundo como um todo, ainda que esse conhecimento da realidade seja imperfeito. Nesse sentido, a educação ocorre quando é confrontada com o meio em que vive.

Contudo, concordamos que estudar o passado, sobretudo as universidades, constituiu uma possibilidade de consolidar nossa identidade e, também, uma forma de entender a construção do conhecimento, do significado da formação, pois essa instituição é um dos locus ${ }^{5}$ onde se encontram as experiências essenciais para o trato com o saber.

Desarraigados de sua origem e de sua história, o homem e as instituições perdem a identidade e, pior do que isso, o endereço. Sem tradição, não existe cultura, nem se preservam os valores que dignificam o ser humano. Da universidade medieval, temos muito que aprender, enquanto nascedouro de ideias perenes, formadora de homens e criadora de uma cosmovisão segura. [...] É preciso que, no mundo acadêmico brasileiro, seja recuperado o atraso nos estudos medievalísticos, os quais, noutros países, já têm longa trajetória e apreço cada vez mais acendrado. (ULLMANN, 2000, p.25).

As palavras de Ullmann são elucidativas no que tange à importância de se estudar

\footnotetext{
5. Ainda que a universidade seja um local em que se consolida a formação docente, temos clareza de que o conhecimento não está restrito à educação institucional, podendo ocorrer de outra maneira e em outros âmbitos.
} 
o passado, especialmente a universidade. Podemos aprender acerca do sentido de formação, do que seja uma academia voltada para a formação das pessoas. Por meio dos autores elencados, entendemos que esse foi o papel das universidades medievais.

Os homens fundam suas instituições em resposta a questões e embates que se colocam em cada época. Na Idade Média, não foi diferente. Guizot corrobora esse entendimento ao afirmar que as instituições e leis humanas são criadas para responder a determinadas necessidades em uma dada época e têm validade enquanto corresponderem a essas necessidades e anseios, ou seja, enquanto possuírem vitalidade.

Observamos que, se uma instituição como a universidade existe há tantos séculos e continua atuante (evidentemente, dentro de novas condições e perspectivas), é porque ela ainda faz parte da História e dispõe de vitalidade. É justamente com esse olhar que procuramos, neste estudo, entender nosso objeto, sem que isso implique criticá-lo ou defendê-lo.

\section{Dois modelos universitários}

Fundamentando-nos em Le Goff (2007), analisamos essa instituição em sua totalidade e procuramos entendê-la como corporação universitária. O termo "universidade”, que significava corporação, apareceu pela primeira vez em 1215, em Paris, para designar a comunidade de mestres e estudantes parisienses, que se constituíam em corporação como os demais ofícios.

Verger (2001) aponta que foram poucas essas primeiras universidades, havendo sete ou oito instituições de fato ativas, sendo elas a de Bolonha, Paris, Oxford, Cambridge, Montpellier, Salamanca, Nápoles, talvez Pádua ou Vercelli.
Ainda a respeito da Idade Média, Le Goff (2007) e Verger (2001), dentre outros autores, ${ }^{6}$ assinalam que essa corporação foi instituída em dois modelos principais: o parisiense e o bolonhês. Traçaremos um paralelo entre esses dois modelos, que fizeram parte das origens das corporações universitárias, não com o intuito de analisá-los detalhadamente, pois isso demandaria outra pesquisa, mas sim para situarmos sua importância na sociedade medieva. Iniciamos com o modelo parisiense que, segundo Verger, tornou-se o foco intelectual no Ocidente medieval, servindo de modelo para as demais universidades.

Le Goff (1995; 2007) registra que, ao longo do século XIII, esse modelo configurou ao mesmo tempo sua organização administrativa e profissional. Era composto por quatro faculdades: Artes, Decretos ou Direitos Canônicos ${ }^{7}$, Medicina e Teologia.

A partir da análise de Verger (2001), observamos a história do nascimento e dos primeiros desenvolvimentos da universidade de Paris. Os documentos considerados pelo autor são pouco numerosos, totalizando 95, dentre os quais ele descreve quatro, a saber, o privilégio de Felipe Augusto ${ }^{8}$ (1200), os Estatutos de Robert de Courson (agosto de 1215), Super Speculam (16 de novembro de 1219) e Parens Scientiarum (13 de abril de 1231).

6. Além destes, Ullmann também aborda os modelos universitários. Sobre essa questão, recomendamos a leitura de seu livro A universidade medieval (2000), especialmente os capítulos V e VI.

7. O papa Honório III proibiu o ensino do Direito Civil em 1219 (LE GOFF, J. Os intelectuais da Idade Média. São Paulo: Brasiliense, 1995).

8. Na primavera de 1200 , alguns estudantes foram mortos por sargentos do rei. Em julho, por meio de um privilégio, Felipe Augusto condenou à prisão ou ao banimento os sargentos culpados e seu chefe (VERGER, J. Cultura, ensino e sociedade no Ocidente nos séculos XII e XIII. Bauru, SP: EDUSC, 2001). 
Segundo Le Goff (2007), os universitários eram regidos por reitores e mestres, e supervisionados pelo chanceler, em geral nomeado pelo bispo local. A importância do chanceler foi silenciada à medida que os universitários ganhavam autonomia. Entretanto, as universidades, em sua maioria, por serem instituições da Igreja, tiveram que aceitar as intervenções pontifícias, como afirma o autor:

Em compensação, as universidades, por serem instituições da Igreja, tiveram de aceitar as intervenções pontifícias. Mas estas foram, em geral, distantes e leves. Em certos casos, o bispo do lugar utilizou o seu poder teórico para intervir brutalmente nos assuntos da universidade e fazer reinar aí uma espécie de censura [...] (LE GOFF, 2007, p.174).

Contudo, o referido autor assevera que houve condenações por parte de alguns bispos que visavam aos empréstimos (tanto reais como supostos) feitos das interpretações realizadas por mestres parisienses. Destacam-se especialmente as ideias de um comentador de Aristóteles, Averróis, cujo ensino pautava-se no que denominou "teoria da dupla verdade", significando que, ao lado da verdade dogmática, ${ }^{9}$ era considerada legítima uma verdade segundo a razão, que podia ser ensinada mesmo que fosse contrária à verdade da Igreja.

Desse modo, observa-se, nas formulações de Le Goff (2007, p.175), que Aristóteles foi um nome expressivo no ambiente da universidade parisiense, e "Embora as suas obras lógicas tivessem sido traduzidas há muito para o latim [...]”, elas ganham notoriedade no século XIII com as traduções latinas que continham sua metafísica, sua ética e sua política. Apesar de, em um primeiro momento, suas obras terem sido proibidas nas universidades,

9. No caso dos cristãos, seria a Bíblia e o ensinamento da Igreja. com o tempo atraíram sobremaneira a curiosidade e o desejo dos estudantes. Um mestre que também estava em evidência era o dominicano Tomás de Aquino, um de seus grandes introdutores na universidade:

Os dominicanos estiveram à frente nas Universidades. Foram mestres, alunos, se envolveram efetivamente na busca do conhecimento. Exatamente por esse envolvimento que vemos os nomes de Alberto Magno e, especialmente, o de Tomás de Aquino presentes e influentes nas Universidades até aos nossos dias. Esses dois mestres estiveram envolvidos e, ao mesmo tempo, criaram um novo filosofar para a humanidade. Criaram a possibilidade de se fundir o pensamento aristotélico à fé cristã. Esta é uma das razões pelas quais Santo Tomás, o irmão dominicano, é considerado o grande mestre da Escolástica (OLIVEIRA, 2005, p.35).

A citação demonstra o envolvimento dos mestres na busca pelo conhecimento e na condução de seus alunos para esse fim. Com eles, observamos a introdução ao pensamento aristotélico, e que este, por sua vez, altera o cenário do saber medieval, pois, como postula Oliveira (2005, p.32):

A razão e o naturalismo presentes nas obras do "Filósofo", como o designará Santo Tomás, colocam em xeque as estruturas do pensamento cristão. A cristandade latina tem que interpretar, assimilar e corrigir o pensamento e é exatamente esse processo que gera a grande crise do conhecimento medievo.

Ao tratarmos do pensamento aristotélico disseminado pelos mestres no ambiente da universidade parisiense, especialmente por Tomás de Aquino, percebemos que esse pensamento possibilitou à cristandade novos debates. Observamos, com isso, a importância desse locus de saber: 
[...] a Universidade de Paris constitui o centro de saber da cristandade latina porque é nela que as duas áreas do conhecimento que permitem um saber totalizante do mundo terreno e divino eram ensinadas: a Teologia e a Filosofia e, sobretudo, o espírito que anima esse fazer Filosofia e Teologia. Tudo que se dizia respeito a um saber mais universal, passava pela Universidade de Paris [...] (OLIVEIRA, 2005, p.30).

A autora sublinha que essa instituição brilhou, influenciando toda a cristandade. Podemos depreender, assim, que a Universidade de Paris foi um foco de debate intelectual e de renovação de idéias. ${ }^{10}$ Os mestres parisienses do século XIII, considerados ilustres, foram os dominicanos Alberto Magno e Tomás de Aquino, além do franciscano Boaventura. Os dois primeiros são considerados ilustres porque, de acordo com Oliveira (2007, p.116):

[...] se dedicaram à investigação da natureza, da natureza das coisas, valorizaram a importância das investigações empíricas e compreenderam e que, para tratar das ciências naturais, era preciso a experiência e o conhecimento de outras autoridades além das sagradas, como Aristóteles [...].

Para Oliveira (2005), tanto os dominicanos quanto os franciscanos, ou seja, as

10. "Renovação de ideias" aqui aparece no sentido de mudanças teóricas trazidas pela filosofia aristotélicas às investigações e ao saberes no seio da sociedade do século XIII. Estudiosos como Steenberghen, Pieper e Gilson salientam três grandes correntes teóricas. A primeira refutava o pensamento aristotélico e lutava pela conservação da concepção agostiniana. A segunda pregava o abandono dos escritos sagrados e o alinhamento radical com o pensamento do filósofo. A terceira mesclava essas duas fontes do conhecimento, procurando unir o pensamento aristotélico com os escritos sagrados. Esse debate foi intenso e marcou a trajetória de quase todo o século XIII e as primeiras décadas do XIV. (OLIVEIRA, 2007, p.121). ordens mendicantes, se opõem à situação estabelecida pela Igreja. Buscavam romper com as tradições de luxo e de poder, porque pregavam a pobreza e a evangelização, e com isso atraíam muitos jovens, os quais, por seu turno, debatiam essa posição (das forças religiosas novas entre as forças tradicionais da Igreja) no interior das universidades, justamente porque seus principais mestres (mencionados anteriormente) eram dessas duas ordens. Esses mestres estavam preocupados com o conhecimento, com as ciências e com a evangelização. Salientamos esse último aspecto dos franciscanos que, na visão de Oliveira (2005, p.35), "se dedicavam com afinco à tarefa de evangelização sem maior atenção para a pesquisa intelectual”.

Passaremos, na sequência, a tecer considerações acerca do modelo bolonhês. Observamos, a partir da análise de Verger (2001), que esse modelo direciona as escolas de Direito de Bolonha, que conquistaram uma expressiva reputação, e sua influência se expandiu para além dos Alpes, desde a metade do século XII. No início de 1190, verificam-se os primeiros traços de uma organização comunitária institucional, que anunciam a passagem à universidade.

Le Goff (1995) assinala que durante um longo tempo, em Bolonha, a Igreja se desinteressou pelo ensino de Direito, pois o considerava uma atividade secular. Foi em 1219 que a universidade recebeu como chefe o arcebispo de Bolonha, o qual parece ter exercido a função de chanceler.

Contra os poderes laicos, observamos com Le Goff (1995) que em Bolonha o conflito entre a universidade e os burgueses foi violento, visto que, em 1278, a Comuna governa a cidade praticamente sozinha, sob a suserania do imperador, e, posteriormente, recebe privilégios do imperador Frederico Barba Ruiva. Le Goff (1995, p.62) complementa, afirmando que: 
A Comuna havia imposto residência permanente aos professores, nomeando funcionários e intervido na colaboração de graus. A instituição do arcediago veio a limitar sua ingerência nos assuntos universitários. Uma série de conflitos, de greves e partida de universitários para se refugiarem em Vicenza, Arezzo, Pádua e Siena, leva a Comuna à conciliação. A última luta teve lugar em 1321. A universidade não precisou mais se submeter às intervenções comunais.

A análise do autor revela os conflitos travados até a instituição conseguir estabilidade com relação ao poder laico, e isso foi possível devido à greve e à secessão travadas pela corporação universitária.

De acordo com Le Goff (1995), verificamos a intervenção e o apoio do papado, seguidos do poder laico. Em Bolonha, Honório III coloca à frente da universidade o arcebispo, que a defende contra a Comuna. Por isso, a universidade é emancipada, já que a cidade reconhece o papa como senhor de Bolonha:

O apoio do pontífice é um acontecimento capital. Sem dúvida, a Santa Sé reconhece a importância e o valor da atividade intelectual; mas suas intervenções não são desinteressadas. Se ela tira os universitários das jurisdições laicas, é para colocá-los sob a jurisdição da Igreja. Assim, para conseguir esse apoio decisivo, os intelectuais se veem forçados a optar pelo caminho da participação eclesiástica, contra a forte corrente que os impulsiona no sentido da laicidade. Quando o papa retira os universitários do controle local da Igreja - não inteiramente, entretanto, pois veremos no decurso desse século a importância das condenações episcopais no domínio intelectual - é para submetê-los à Santa Sé, integrá-los em sua política, importa-lhes seu controle e seus fins (LE GOFF, 1995, p.63).
Le Goff (1995) revela que novas ordens aparecem para essa instituição, porque o apoio do papado, assim como da realeza, via essas instituições como pontos de apoio político e cultural. Por isso, editaram bulas e leis, a fim de instituí-las, protegê-las e nelas intervir.

Observamos, a partir do excerto, que essa instituição é uma corporação eclesiástica, ainda que seus membros não sejam ordenados e que contem com uma expressiva quantidade de leigos. Na concepção do autor, os intelectuais são considerados clérigos e dependem da jurisdição eclesiástica.

Verger discorre sobre alguns aspectos da originalidade do modelo bolonhês:

Para compreender bem a originalidade do fenômeno bolonhês, é preciso evidentemente lembrar que os estudantes que vinham frequentar as escolas de Direito, eram normalmente jovens já maduros, geralmente de um certo nível social ou mesmo nobres, consequentemente bastante seguros e dispondo de muitos meios. A maioria deles era estrangeira na cidade e muitos vinham de além dos Alpes. A exemplo de certos mercadores, eles criaram o hábito de se agrupar em "nações”, segundo sua origem geográfica (VERGER, 2001, p.212-13).

Acresce-se que os universitários se agrupam de acordo com sua origem geográfica, resultando no que o autor denomina "confrarias", as quais seriam denominadas mais tarde universitates. Verger pontua que essa nova forma de associação calcou-se na consciência dos estudantes e até em seus mestres, cujo curso acompanhavam. Disso resultaram o aparecimento de confrarias religiosas e o agrupamento de profissões.

Inicialmente, nações e universidades eram simples associações de ajuda mútua, como preconiza Verger (2001), e, após 
algumas intervenções entre 1224 e 1250, sobretudo pontifícias, o Papa, os mestres e os estudantes reuniram-se contra o imperador Frederico II, que almejava arruinar as escolas bolonhesas em detrimento do studium que ele acabara de criar em Nápoles. Devido a isso, a universidade de Bolonha assumiu uma forma institucional quase estável e definitiva.

À medida que estudamos a corporação universitária, compreendemos um pouco mais da trajetória dos intelectuais que dela fizeram parte. Contudo, é preciso citar o método desenvolvido nessa ambiência e difundido pelos intelectuais. Nesse intento, analisamos, a seguir, a herança da atividade intelectual, ou seja, o método escolástico, relacionando-o com o florescimento da vida urbana estimulada por artesãos e mercadores.

\section{Método de ensino do século XIII: a escolástica}

Vimos que a sociedade medieval baseava-se na agricultura e que o renascimento comercial foi caracterizado não apenas pela demanda populacional, mas também pelo crescimento técnico do trabalho rural, e que esses desenvolvimentos proporcionaram, efetivamente, o progresso da sociedade de forma geral, em todos os elementos das cidades e do comércio.

Nesse contexto, destacamos a abordagem de Henri Pirenne (1964, p.109-10). Ele afirma que em nenhuma civilização a vida urbana se desenvolveu independentemente do comércio e da indústria. Complementa afirmando que um aglomerado urbano só pode subsistir pela importação de gêneros alimentícios que traz de fora. Estabelecerse-á sempre entre a cidade e seus vizinhos uma relação de serviço.

Pirenne assevera que o comércio e as atividades artesanais são indispensáveis para a manutenção dessa recíproca dependência: sem a importação que assegura o reabastecimento, sem a exportação que compense os objetos de troca, a cidade morrerá. Notamos uma situação de simultânea dependência na sociedade medieva, pois a cidade necessitava do campo e vice-versa.

Essa mútua dependência e reciprocidade entre campo e cidade para o florescimento do que viria a ser a Europa Moderna também é analisada por Le Goff na obra As raízes medievais da Europa. Nela, o autor evidencia a função das cidades como um processo de formação inovador, o espírito de liberdade e a mentalidade social que culminariam na mistura da população e na criação de novas instituições.

[...] a cidade medieval conserva, e até reforça, uma mentalidade urbana que é uma parte importante da sua originalidade e do seu poder. A oposição cidade/campo, que equivale mais ou menos à civilização/ barbárie, já era forte no mundo romano. É mais forte ainda na Idade Média, quando se sabe que a massa camponesa era formada, em toda a cristandade, por pessoas que eram chamadas de "vilãs", e que durante muito tempo conservaram um status de "não livres", de escravos, depois, de servos, ao passo que citadinos e livres coincidiam. Um provérbio alemão, que apareceu, aliás, na Idade Média, diz "o ar da cidade liberta" (Stadtluft macht frei) (LE GOFF, 2007, p.145).

Destacamos o espírito de liberdade e urbanidade mencionado pelo autor, uma vez que este só se fez possível nas cidades em razão das mudanças de comportamento, do amparo legal que foi criado e, sobretudo, em virtude do nascimento de uma nova posição e uma nova compreensão do significado de se viver em comunidade, oriundo da circulação do comércio e de saberes. Desse modo, é necessário considerar esse espírito de 
liberdade e urbanidade como a espinha dorsal da mistura da população e do surgimento de novas instituições. Para isso, iremos nos apoiar também em Oliveira (2005).

Na passagem a seguir, fica explícito o desenvolvimento do ensino nas cidades. Le Goff inclusive aponta números sobre esse processo.

\begin{abstract}
A importância dessa atividade escolar varia segundo as regiões e as cidades, mais atinge, frequentemente, $60 \%$ das crianças das cidades, ou até mais. E em certas cidades, como em Reims, por exemplo, atinge também as meninas. Mas se notará, sobretudo para a nossa finalidade, a criação e o sucesso rápido de centros que diríamos de ensino superior, as universidades. Elas atraem numerosos estudantes; apelam para mestres muitas vezes renomados e até ilustres; é lá que se elabora um novo saber, resultado das pesquisas do século XII, a escolástica. Finalmente, o quarto acontecimento, que sustenta e alimenta os três outros. Tratase da criação e extraordinária difusão, em cerca de trinta anos, de novos religiosos que residem na cidade e são ativos, sobretudo no meio urbano, os frades das ordens mendicantes, que formam a nova sociedade e remodelam profundamente 0 cristianismo que ela professa (LE GOFF, 2007, p.144).
\end{abstract}

Nas cidades, encontramos os estudantes, os mestres mendicantes que promovem um "verdadeiro borbulhar de saberes". E a universidade é seu espelho, ou seja, há o desenvolvimento da corporação universitária e com ela o método de ensino, a difusão de novas ordens religiosas. Nesse âmbito, observamos a cidade como centro de transformações sociais e culturais, e a percebemos como um borbulhar de saberes, porque essas novas demandas culminaram na gestação das universidades - nas quais encontramos a manifestação e a universalidade ${ }^{11}$ do conhecimento.

Assim, observamos que os séculos XII e XIII expressam o florescimento da vida urbana estimulada pela atividade dos artesãos e dos mercadores, e nesse cenário assistimos ao amadurecimento do principal método de ensino recorrente na universidade, a escolástica. De acordo com Le Goff (2005, p.75), “a escolástica é uma das filhas das cidades, e reina nas instituições novas, as universidades, corporações intelectuais”.

Oliveira preconiza, em Escolástica (2005), que a escolástica não pode ser reduzida a um método intelectual isolado, resultante da capacidade fecunda de alguns sábios medievais. Ela constitui a essência do pensamento medieval, da qual os homens desse tempo obtinham os saberes e valores que regulamentavam suas relações sociais.

Le Goff (2007) contribui para o debate dessa importante herança da atividade intelectual do século XIII, cujo conjunto de métodos e de obras foi classificado sob o nome de escolástica. Esse termo significa, em conformidade com o autor, a produção intelectual ligada à escola a partir do século XII, e mais especificamente às universidades no século XIII.

A escolástica, na concepção de Le Goff (2007), advém do desenvolvimento da dialética, uma das disciplinas do trivium.

11. Consideramos universalidade ou universalizante, a partir dos estudiosos como Pieper e Oliveira, dentre outros. Com relação à universalidade, conforme postulado por Pieper (1989), o conceito se refere ao caráter de todo (único) e uno da realidade, ou seja, na perspectiva da totalidade, de formar o homem por inteiro, em sua condição de ser inteligente, sensível e espiritual. "Universalizante" diz respeito ao conhecimento e no que respeita a integridade das pessoas, à medida que atentemos para o fato de que a universidade, segundo Oliveira (2007), tenha sido o primeiro espaço de saber universalizante que o Ocidente construiu nos últimos dois mil anos. 
O autor destaca Anselmo de Cantuária (10331109) como o pai da escolástica. Sobre esse método, Oliveira (2005) cita três momentos, a saber: o seu nascimento, com Boécio, o seu florescimento, com Santo Anselmo, e o seu apogeu, com Tomás de Aquino.

Le Goff (2007, p.185), seguindo as formulações de Anselmo de Cantuária, afirma que este concebia a dialética como método de base à reflexão ideológica. Nesse sentido, a meta da dialética é a inteligência da fé, cujo procedimento implica o recurso à razão:

[...] A meta da dialética é a inteligência da fé, cuja fórmula ficou célebre desde a Idade Média, fides quarens intelectum. Esse procedimento implica o recurso à razão, e Anselmo completou a sua doutrina pela ideia da compatibilidade entre o livre-arbítrio e a graça. A escolástica pode ser considerada como o estabelecimento e a justificação de uma concórdia entre Deus e o homem. Anselmo também forneceu à escolástica um fundamento, as provas da existência de Deus segundo um procedimento racional. [...]

Desse modo, o autor explica que a escolástica pode ser considerada como o estabelecimento e a justificação de uma concórdia entre Deus e o homem, isto é, entre fé e razão. Ao abordar esse pensamento, Le Goff (2007) descreve como o método escolástico foi gestado no século XII, denominando como "experimentação" o início de sua difusão naquele século.

A experimentação, no século XII, de um novo método de reflexão e de ensino foi o prólogo do método propriamente escolástico das universidades. Trata-se, primeiro, de construir um problema, de apresentar uma quaestio, e essa quaestio era discutida (é a disputatio) entre o mestre e os alunos. Enfim, o mestre dá a solução do problema após essa discussão; é a determinatio. No século XII, no programa das universidades apareceram, duas vezes no ano, dois exercícios em que se manifestava o talento intelectual dos mestres, as questões quodlibetais, em que os estudantes punham ao mestre uma questão acerca de qualquer problema, à sua escolha. A reputação dos mestres muitas vezes se fazia em cima de sua capacidade de responder a essas questões (LE GOFF, 2007, p.185-6).

A citação indica o fundamento desse ensino baseado no método escolástico, isto é, levar os estudantes à reflexão. Esse método, embora ganhe corpo no século XIII, é desenvolvido no século XII. Assim, o ensino universitário conduz a publicações cuja finalidade se explica na difusão e na promoção dos livros por parte das universidades.

Ainda sob a influência de Le Goff (2007), observamos que no século XIII as produções escolásticas se exprimem em duas formas: os comentários ${ }^{12}$ e as sumas ${ }^{13}$. Dentre os célebres escolásticos e suas sumas, podemos citar Alberto Magno, o mestre de Tomás de Aquino, autor de uma imensa obra, na qual se destacam a Suma Teológica (obra inacabada em decorrência de sua morte) e a Suma contra os gentios (1259-1265).

Nessa perspectiva, realçamos a importância do propósito de Alberto Magno que, segundo Oliveira (2005), consistiu na

12. Com a disputatio, o comentário foi o aguilhão essencial do desenvolvimento do saber no século XIII. Graças ao comentário, pôde ser elaborado um saber original produzido pelos mestres em função das preocupações contemporâneas, mas apoiando-se na tradição e fazendo-a evoluir. A Europa dos comentários inaugura a Europa do progresso intelectual, sem ruptura com a tradição (LE GOFF, 2007, p.187).

13. O próprio nome de suma exprime o desejo dos intelectuais do século XII de oferecer uma síntese documentada e argumentada de uma filosofia que não estava ainda separada da teologia (LE GOFF, 2007, p.187). 
tarefa de difundir no seio da cristandade o pensamento aristotélico. Suas formulações conduziram a um novo horizonte para o pensamento escolástico. Dessa forma, os homens continuaram crendo que Deus é o criador de todas as coisas da natureza, porém as coisas da natureza poderiam ser conhecidas pelos homens por meio da razão, conforme explicitam os autores estudados.

Ainda sobre a relevância de Alberto Magno para o desenvolvimento da filosofia cristã e, por conseguinte, para a compreensão da Escolástica, Oliveira (2005) ressalta um aspecto crucial para essa apreensão: a sistematização das obras aristotélicas (razão/ filosofia) com a ideia evangelizadora da encarnação (fé/teologia). Essa autora postula que, mesmo tendo sido Alberto Magno um dos maiores divulgadores do pensamento aristotélico, ele não pode ser classificado apenas como tal, pois também foi um profundo conhecedor dos escritos agostinianos.

Neste sentido, Tomás de Aquino, discípulo de Alberto Magno, também teve sua importância retratada pela história da educação medieval. Para a vertente estudada por Oliveira (2005), Aquino prioriza a necessidade de se compreender as questões humanas em sua totalidade, por isso observa-se seu afinco nos escritos. O século XIII, segundo a autora, demonstrou à humanidade que o ser humano é um único ser - matéria e espírito. São justamente esses dois elementos que compõem a totalidade humana. Com isso, o mestre revolucionou o pensamento cristão tradicional, pois até então apenas a alma era concebida como aspecto essencial do homem.

Essa questão analisada por Oliveira também é destacada, anteriormente, ${ }^{14}$ por Le Goff:

14. Ressalta-se “anteriormente" pois, embora tenhamos utilizado a obra de Le Goff traduzida para a língua portuguesa, As raízes medievais da Europa (2007), essa obra, originalmente intitulada L'Europe est-elle née au Moyen Age?, data de 2003.

\begin{abstract}
Segundo Tomás, o homem é um homem total. Não somente uma criatura de Deus, que é um animal racional, mas é também um “animal social e político" que se serve, para manifestar a sua individualidade, de um dom essencial de Deus, a linguagem. De maneira geral, os escolásticos deram uma atenção muito grande à linguagem, e têm o seu lugar numa história europeia da linguística (LE GOFF, 2007, p.188).
\end{abstract}

Verifica-se que as formulações de Le Goff (2007) e Oliveira (2005) compartilham uma mesma interpretação, a de que o ser humano é um único ser, dotado de matéria e espírito, por isso é considerado ser total. Os escolásticos são exemplo disso, porque buscam explicar as relações humanas e praticar as ciências, sobretudo a filosofia, ou seja, buscam explicar o homem em sua fé e em sua natureza humana em uma dada época histórica.

Portanto, vê-se com os autores estudados - especialmente com Oliveira (2005) -, que este era o cenário no século XIII: um cenário de profundas inovações, que influenciaram o encaminhamento da filosofia cristã/ escolástica. Ao começar pela expressiva entrada do pensamento aristotélico (tanto por traduções árabes quanto pelos próprios ocidentais). A fundação das Universidades, das Ordens Mendicantes, as disputas travadas entre as relações políticas da época (sobremaneira entre a realeza e o papado), causaram grandes perturbações ao Ocidente, seja pelas transformações sociais, seja pelas diferentes correntes teóricas oriundas da cristandade, sob a base dos escritos de Alberto Magno, Tomás de Aquino e Boaventura.

\section{Considerações finais}

No decorrer de nosso estudo sobre a origem da universidade medieval no século 
XIII, pudemos observar que essa instituição revela certa complexidade que incide no processo de desenvolvimento do homem na sociedade como um todo. Desse modo, acreditamos que os autores elencados nos possibilitaram não somente compreender o contexto histórico em que essa instituição foi gestada, mas também suscitaram alguns aspectos para refletirmos sobre a natureza humana e a educação da época.

Salientamos que o estudo no campo da História da Educação permitiu-nos compreender um pouco mais sobre a maneira como construímos nosso conhecimento, nossas instituições. Notamos que o conhecimento da história constitui condição essencial para a compreensão do passado, de como os homens se relacionavam, como eram suas relações sociais e políticas, e o que delas resultou.

"A incompreensão do presente nasce fatalmente da ignorância do passado. Mas talvez não seja menos vão esgotar-se em compreender o passado se nada se sabe do presente”, disse Bloch (2001, p.65). Por isso, ao considerar a vivência do homem no passado, é preciso considerá-la sob a perspectiva de totalidade, ou seja, lançando mão de um cotejamento entre passado e presente.

Evidentemente, o contexto histórico medieval é muito distante da realidade dos homens da atualidade. Porém, a formação do que somos no presente provém, de certa maneira, da forma como esses homens e dos homens anteriores a eles consideraram a educação. Nesse contexto, a História assume um valor prático importante, pois possibilita analisar a permanência de algumas condutas humanas, mesmo diante de profundas modificações dos acontecimentos.

Enfim, pudemos constatar que a essência da formação docente reside na reflexão e no constante trato com o conhecimento, procurando saber como constituímos nossos espaços de formação, procurando despertar em nossos alunos o desejo pelo saber, por reconhecer nos livros, nas pessoas, nos atos, hábitos, enfim, em tudo que nos permeia, o que há de essencial, pois a formação não se restringe a apenas um aspecto. Ela deve ser considerada em seu conjunto, em sua totalidade, primando pelo sentido de humanitas.

O sentido de formação docente está interligado ao sentido de formação humana e intelectual, na medida em que procuramos entender as relações que se processam na sociedade. Por isso, compreendemos que, onde houver pessoas, haverá processo educativo, independentemente do momento histórico. É dessa forma que concebemos a relevância dos estudos em História da Educação Medieval e das obras dos autores contemporâneos estudados para a formação de educadores na atualidade.

\section{Referências}

BLOCH, M. Apologia da história ou o ofício do historiador. Rio de Janeiro: Jorge Zahar Ed., 2001.

CATRO, H. História social. In: CARDOSO, C. F.; VAINFAS, R. (Orgs.). Domínios da história: ensaios de teoria e metodologia. Rio de Janeiro: Elsevier, 1997.

HUGO DE SAINT-VICTOR. Didascálicon: da arte de ler. Petrópolis: Vozes, 2001.

LE GOFF, J. A civilização do Ocidente medieval. Bauru: EDUSC, 2005.

As raízes medievais da Europa. Petrópolis: Vozes, 2007.

História e memória. Campinas: Editora da Unicamp, 2003.

Os intelectuais na Idade Média. São Paulo: Brasiliense, 1995. 
OLIVEIRA, T. As universidades na Idade Média (séc. XIII). São Paulo: Mandruvá, 2005.

2005.

Escolástica. São Paulo: Mandruvá,

. Origem e memória das universidades medievais: a preservação de uma instituição educacional. Varia História, Belo Horizonte, vol. 23, n. 37: p.113-29, Jan/Jun 2007.

. Universidade e cultura na ambiência citadina do século XIII: um olhar sobre os mestres Tomás de Aquino e Boaventura. In: OLIVEIRA, T. (Org.). História e historiografia da educação nos clássicos: estudos sobre Antiguidade e Medievo. Dourados: UEMS, 2010.

LIBÂNEO, J. C. Pedagogia e pedagogos, para quê? São Paulo: Cortez, 1998.

PIEPER, J. A abertura para o todo: a chance da Universidade. São Paulo: Apel Editora, 1989.

PIRENNE, H. As cidades da Idade Média. Lisboa: Publicações Europa-América, 1964.

VERGER, J. Cultura, ensino e sociedade no Ocidente nos séculos XII e XIII. Bauru: Edusc, 2001.

ULLMANN, R. A. A universidade medieval. 2. ed. Porto Alegre: Edipicurus, 2000.

Enviado em: 30/09/12

Aceito em: 21/06/2013 